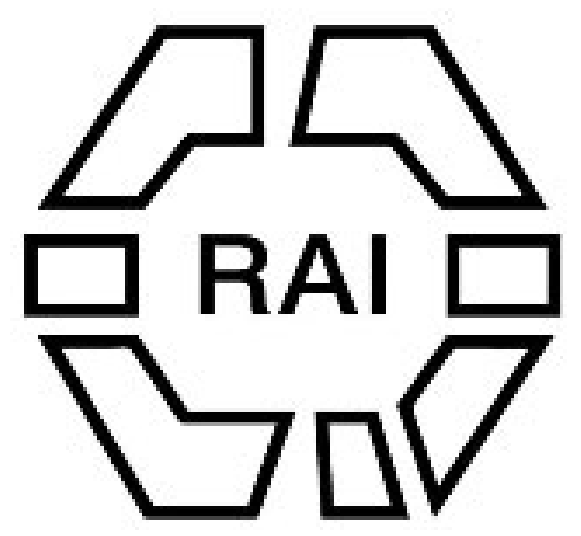

21. On a Recent Discovery of Rock Sculptures in Derbyshire.

Author(s): G. A. Garfitt

Source: Man, Vol. 21 (Mar., 1921), pp. 35-37

Published by: Royal Anthropological Institute of Great Britain and Ireland

Stable URL: http://www.jstor.org/stable/2840421

Accessed: 29/12/2014 23:03

Your use of the JSTOR archive indicates your acceptance of the Terms \& Conditions of Use, available at http://www.jstor.org/page/info/about/policies/terms.jsp

JSTOR is a not-for-profit service that helps scholars, researchers, and students discover, use, and build upon a wide range of content in a trusted digital archive. We use information technology and tools to increase productivity and facilitate new forms of scholarship. For more information about JSTOR, please contact support@jstor.org.

Royal Anthropological Institute of Great Britain and Ireland is collaborating with JSTOR to digitize, preserve and extend access to Man. 
Rather more than 100 years later, at the election of a new Diwan, a dispute arose between the people of Wassein and Vumba-Kuu as to the merits of rival candidates, and neither party giving way the matter was referred to the Arab Governor of Mombasa, who decided that each town should have its own Diwan. It was on this occasion that the drums and horn now kept at Wassein were made, the original ones being returned to Vanga.

There are two drums of similar size (Fig. 3) made like the original from the stem of the Borassus palm and measuring 3 feet 4 inches by 2 feet. The third drum is far more ornate (Fig. 4). All three are in a good state of preservation. Fig. 5 shows an inkstand, which also belonged to the Diwan of Wassein, and is interesting in as far as it shows the sequence of idea of the carving of a bird's head which appears on the large drum. This is referred to as "Tausi "* (peacock), but no explanation is given as to its significance.

The horn (Fig. 6) is of no particular merit and shows no ornamentation.

The third or largest drum (Fig. 4) is still used at marriages and deaths, and I was present in May last at the ceremony of praying for rain which was held in the plantation and at which the drum was beaten as an accompaniment to the chanting of prayers.

These and the ruins of a few mosques along the coast seem to be all the material evidence that is left of what must have been once an important Persian colony, but careful research shows that many prevailing customs owe their origin to the same authorship.

Of these I will only mention two. The first, a very striking one in a Mahomedan country, of uncovering the head in the presence of any person of importance originated in the custom of appearing bareheaded before the Sultan or Diwan.

The second has come to my notice while I write. The headman of the neighbouring village or Kichangani has just died and every one living in the village or in any way connected with it, is going about bareheaded for three days. This is a survival of the original form of mourning for the Diwan which prescribed that nobody might shave, wear a fez or turban or more than one cloth for his body for a period of forty days.

T. AINSWORTH DICKSON.

\section{Derbyshire: Ethnography.}

\section{On a recent Discovery of Rock Sculptures in Derbyshire. By 2}

The illustrations show two sculptured stones, of which one was found this year on Eyam Moor, near the stone circle. The other came from Great Hucklow, a place three miles away on the same plateau, and it is now in the Weston Park Museum, Sheffield.

Another stone, not illustrated, bears cup marks with channels. There are a number of stones near by with cup marks, and these are also found on one of the stones of the circle. There had been a cup and ring stone 600 yards away, but it has disappeared.

The first stone also bears two cup marks near the summit, but its principal interest is in two articles of deer-horn very realistically represented. There are some more artificial markings on the stone, but they are lightly incised and are probably indecipherable. The upper horn represents a pick or hoe such as was found at the base of megaliths at Stonehenge, and is of frequent occurrence in Grimes Graves. The lower one is the whole of a first year's antler of the red deer, and in my opinion represents a plough or harrow.

These designs have never been discovered before, but the nearest approach to them is in the sculptured stones of the French dolmens. Under the covering

\section{* Tausi is the Persian word for peacock.}


stone of the "Table des Marchands" there is a crook similar in shape to our hoe, and also a hache emmanché, or handled celt. These articles have been shown by M. Le Rouzic to be agricultural implements, and to be an emblem of the goddess

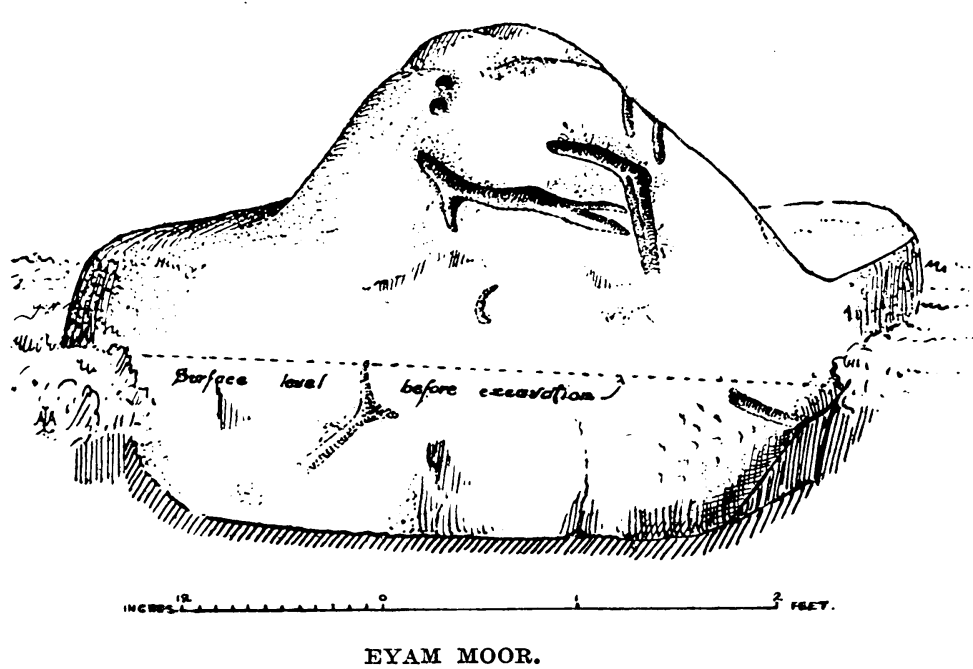
of fertility. In the tomb of Chamhouti, who was an intendant of the Royal domains in Egypt of the XVIII dynasty, there are scenes showing men breaking up the ground with hoes, followed by a man sowing seed, with a harrow following after.

In the figure at Saint Sernin in the Aveyron, the goddess has an anthropomorphic form, but in that at Castlenau this has almost disappeared, and is replaced by these two articles. This proves that our stone with two designs is equivalent to an idol of the goddess. The reason that our plough is not a handled celt is that there is no flint in our country, and, besides, the red deer horn seem to have been the standard implement for digging.

The other stone bears seven horseshoe curves. The portion to the left is broken off. and I am afraid that the fragments are now lost. The design was not

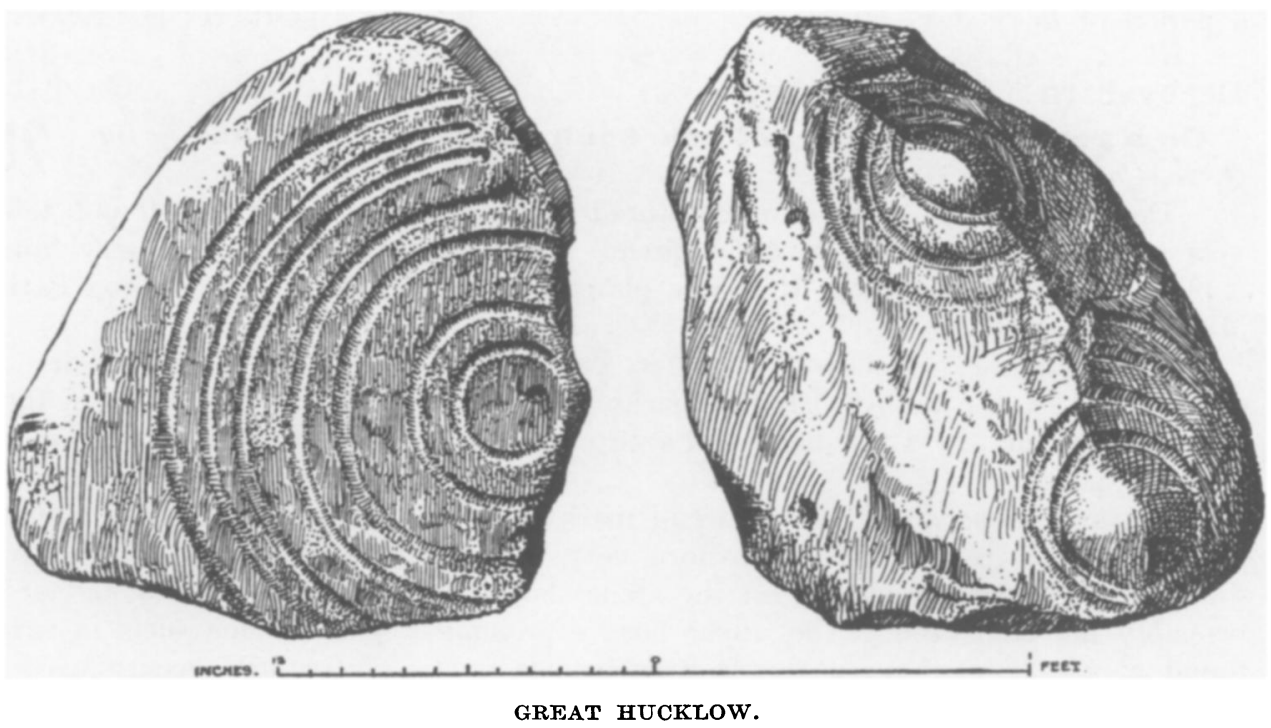

meant to be a complete ellipse. It is seen that the lines finish before reaching the edge of the stone. In the centre there is a slightly raised boss.

The design is similar to the sculptured signs in the allée couverte at Gavr'inis and at New Grange in Ireland. 
My suggestion is that this is also the equivalent of an idol of the goddess, The figure at Saint Sernin wears a necklace. Everything about her is symbolical. and I think that the necklace is the sun symbol of concentric circles. Being a necklace, it has a little swag, and the reason that it is only half a sign is simply that the statues, of which there are many, are only carved in front. At New Grange, however, there are two of these designs carved as complete ellipses, and on the back of this stone there are two more sculptures which so strongly support my theory that I think they prove it. There is a ridge upon which stands a boss, which may be taken as a head, and surrounding it are two well-made engravings in elliptical form which fall down at each side of the ridge. It will be remembered that the front of the stone also has a boss. The other design has the same idea, but is incomplete.

When the necklace was engraved on other stones, either the front part only or complete, people recognised it as a sign of the goddess of fertility.

Neither of these symbols has ever before been found in Britain. They prove that the cult of the goddess of fertility or earth spirit extended from France to the Peak of Derbyshire. These plateaux were populous in the neolithic and bronze ages.

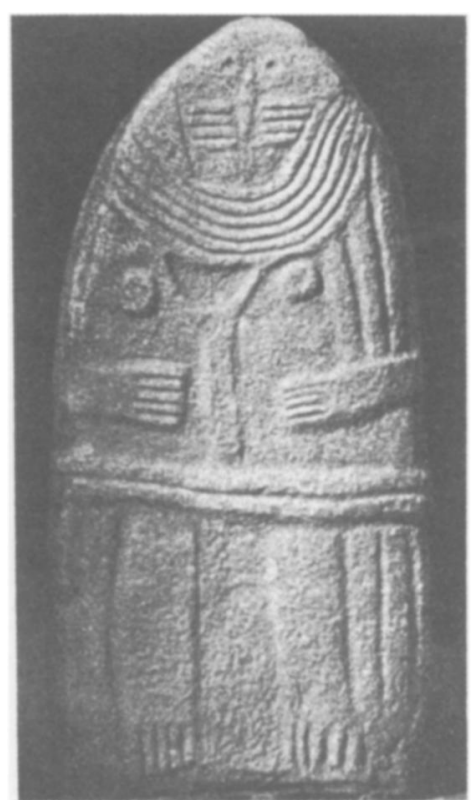

ST. SERNIN, AVEYRON.

This stone was given to the Sheffield Literary and Philosophical Society in 1824. It was figured by Geo. Tate, F.S.A., in his Sculptured Rocks of Northumberland in 1865, and by Sir J. Y. Simpson in his Archaic Sculpturings, in 1867. When Sheffield formed a public museum, the stone, with other objects, was handed over, but its label had been lost, and it has lain for 48 years, out of doors, unrecognised.

I am indebted to Mr. A. Leslie Armstrong, M.C., F.S.A. (Scot.), for the photographs, the line drawings, and for much general assistance in the research.

G. A. GARFITT.

Central America: Chronology.

Long.

The Setting in Order of Pop in the Maya Calendar. By Richard 22
E. Long.

In the Book of Chilan Balam, of Tizimin, is the entry, "The 13th Ahau; then "Pop was counted in order," and in the Book of Chilan Balam, of Chumayel, "The 13th Ahau; Pop was set in order." These are Brinton's translations, but properly cardinal numbers should be used instead of ordinals, so as to read (katun) 13 Ahau instead of the 13th Ahau. This katun 13 Ahau would, as explained in my former papers (MAN, 1918, 70, 74; 1919, 20, 29), be equivalent to 10-10-0-0-0 13 Ahau $13 \mathrm{Mol}$ in the Long Count and to 31st August 498 A.D.; but as the Books of Chilan Balam only specify the katun in which this event occurred, it may have been either on that day or on any other date between that and the next katun 10-11-0-0-0 11 Ahau $13 \mathrm{Zip}, 18$ th May 518. If any explanation could be found of the meaning of these statements it would throw much light on the Maya calendar as a whole, especially on the correlation of the Long Count dates with those in the Christian era.

Now it has been shown by Dr. Forstemann that all the Long Count calculations in the Dresden Codex lead up to and centre round the number 9-9-16-0-0 $(=72$ 